\section{Influence of Sublethal Glyphosate Rates on Leaf Mineral Concentration of Tomato}

\author{
James P. Gilreath ${ }^{1}$ \\ Gulf Coast Research and Education Center, University of Florida, Bradenton, \\ FL 34203
}

Carlene A. Chase and Salvadore J. Locascio

Horticultural Sciences Department, University of Florida, Gainesville, FL 32611-0690

Additional index words. herbicide, herbicidal drift, Lycopersicon esculentum

\begin{abstract}
Glyphosate at sublethal rates was applied prebloom, at-bloom, or postbloom relative to the first flower cluster to tomato (Lycopersicon esculentum Mill.) to determine

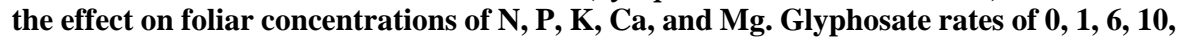
60 , and $100 \mathrm{~g} \cdot \mathrm{ha}^{-1}$ were used to simulate the effects of spray drift. In three studies, plant vigor declined with increased glyphosate rates and younger plants were more sensitive than older plants. Plant height decreased as glyphosate rate increased, but the response differed with time of evaluation and with stage of development. In Expt. 1, $\mathrm{N}$ content decreased with increasing rate of glyphosate, regardless of stage of development, but response varied with time of evaluation with prebloom and at-bloom applications. In Expt. 2, prebloom glyphosate applications reduced $\mathrm{N}$ content, but applications at-bloom did not. $P$ declined with prebloom and at-bloom glyphosate applications in Expt. 1, but only with prebloom applications in Expt. 2. In Expt. 3, P concentrations generally declined with glyphosate rates $\leq 10 \mathrm{~g} \cdot \mathrm{ha}^{-1}$, but were unchanged or increased with rates of 60 and 100

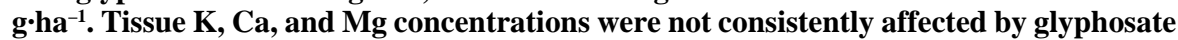
rate and sample times. Although significant changes in foliar concentrations of $N, P, K, C a$, and $\mathrm{Mg}$ occurred, leaf mineral analysis was not considered to be a reliable method of quantifying sublethal effects of glyphosate in tomato. Mineral deficiency did not occur in response to glyphosate application. Chemical name used: $N$-(phosphonomethyl)glycine (glyphosate).
\end{abstract}

Glyphosate is a broad-spectrum, nonselective, postemergence herbicide with activity against most annual and perennial plants (Franz, 1985). Its primary mechanism of action is the inhibition of the biosynthesis of aromatic amino acids (Cole, 1985). Its effectiveness has led to widespread use, which is expected to increase with the continued development and adoption of transgenic crops with resistance to glyphosate (Powles et al., 1998). Increased usage will present greater opportunities for the occurrence of spray drift and injury to susceptible nontarget crops. In Florida, a variety of horticultural crops are often grown in close proximity. Glyphosate is used for weed control prior to land preparation for a new crop, for perimeter and ditch bank weed control of established crops, and for weed management in perennial crops such as citrus. Spray drift in such situations poses a problem to adjacent crops, the extent of

Received for publication 18 Oct. 1988. Accepted for publication 8 Mar. 2000. Florida Agricultural Experiment Station Journal Series No. R-07352. The cost of publishing this paper was defrayed in part by the payment of page charges. Under postal regulations, this paper therefore must be hereby marked advertisement solely to indicate this fact.

${ }^{1}$ To whom requests for reprints should be addressed. E-mail address: DrGilreath@aol.com which bears further investigation. Simulated drift studies have been conducted to evaluate the effect of sublethal rates of glyphosate on the yield of processing tomato (Romanowski, 1980). Total yields were reduced by 100 $\mathrm{g} \cdot \mathrm{ha}^{-1}$ glyphosate applied in early or midseason; however, yield was unaffected by late-season exposure.

Although the effect of sublethal glyphosate rates on foliar mineral content of tomato has not been previously reported, investigations of glyphosate effects on ion uptake and translocation have been conducted with 'Eastern Butterwax' bean (Phaseolus vulgaris L.) and 'Hill' soybean [Glycine max (L.) Merr.]. Brecke and Duke (1980) found that glyphosate inhibited the absorption of ${ }^{86} \mathrm{Rb}$ and ${ }^{32} \mathrm{P}$ by bean leaf cells. Duke et al. (1983) reported that when roots of soybean seedlings were exposed to glyphosate, uptake of $\mathrm{Ca}$ was unaffected, but the translocation of $\mathrm{Ca}$ to leaves and cotyledons was significantly reduced. They suggested that this could partially account for severe retardation of leaf growth by glyphosate. In subsequent studies, the effects of glyphosate on Ca were compared with those on $\mathrm{Mg}$ and $\mathrm{K}$. Uptake and translocation of $\mathrm{Ca}$ and $\mathrm{Mg}$, but not of $\mathrm{K}$, were reduced by foliar or rootapplied glyphosate (Duke et al., 1985). The objectives of the present studies were to evaluate the effects of sublethal rates of glyphosate applied at three stages of development on vigor, height, and foliar $\mathrm{N}, \mathrm{P}, \mathrm{K}, \mathrm{Ca}$, and $\mathrm{Mg}$ concentrations of fresh-market tomato plants. Characteristic changes in mineral composition may aid in diagnosing glyphosate drift injury, and adjusting nutrition to ameliorate the inhibition of growth and yield that occurs with nonlethal exposure to glyphosate.

\section{Materials and Methods}

The effect of glyphosate rate on foliar mineral content was assessed in three experiments conducted at Bradenton, Fla. The experimental designs were randomized complete blocks with five replications in Expt. 1 and six replications in Expts. 2 and 3. Fifteen-cm high raised beds were prepared, fertilized with $336 \mathrm{~kg} \cdot \mathrm{ha}^{-1}$ of $\mathrm{N}$ and 465 $\mathrm{kg} \cdot \mathrm{ha}^{-1} \mathrm{~K}$ from an $18 \mathrm{~N}-0 \mathrm{P}-30 \mathrm{~K}$ formulation applied in two bands, fumigated with 392 $\mathrm{kg} \cdot \mathrm{ha}^{-1}$ of a $67 \%$ methyl bromide $+33 \%$ chloropicrin mixture, and covered with polyethylene mulch. The experiments were conducted on an EauGallie fine sand (sandy, siliceous, hyperthermic, Alfic Haplaquod), which was subsurface-irrigated. Tomato plants, cultivar Sunny, were transplanted on 23 Feb. 1988, 13 Sept. 1988, and 17 Feb. 1989. In each experiment, glyphosate (Roundup $4 \mathrm{E}^{\circledR}$ ) was applied at three stages of development at $0,1,10$, and $100 \mathrm{~g} \cdot \mathrm{ha}^{-1}$. Because significant responses were obtained with 10 and $100 \mathrm{~g} \cdot \mathrm{ha}^{-1}$ glyphosate in Expts. 1 and 2, additional rates of 6 and $60 \mathrm{~g} \cdot \mathrm{ha}^{-1}$ were included in Expt. 3. Prebloom (for first cluster) sprays were applied at 4 weeks after transplant (WAP) in Expts. 1 and 2, but at 3 WAP in Expt. 3. Glyphosate was applied at bloom 5 WAP and the postbloom applications were made 7 to 8 WAP.

In Expt. 1, eight plants per plot were spaced $0.46 \mathrm{~m}$ apart on 0.76-m-wide beds with an inter-row spacing of $1.37 \mathrm{~m}$. In Expts. 2 and 3, ten and eight plants per plot, respectively, were spaced $0.61 \mathrm{~m}$ apart on 0.81 -m-wide beds with a 1.52-minter-row spacing. In Expts. 1,2 , and 3 , nonplanted alleys at the end of each plot were $2.44,1.52$, and $1.22 \mathrm{~m}$, respectively; and treatment rows were separated by a guard row in all experiments.

Plant vigor was assessed, plant height was measured, and the youngest mature leaf was sampled from each plant in the row for leaf nutrient analysis at 7, 14, 21, and $28 \mathrm{~d}$ after treatment (DAT). Plant vigor was evaluated visually using a 0 to 10 scale. A vigor rating of 0 indicated that all plants were dead, while 10 represented optimum plant growth. Leaf samples were dried at $70^{\circ} \mathrm{C}$ and ground to pass a 40-mesh screen prior to determination of total $\mathrm{N}, \mathrm{P}, \mathrm{K}, \mathrm{Ca}$, and $\mathrm{Mg}$ concentrations. Tissue was digested by micro-Kjeldhal procedures and total $\mathrm{N}$ was determined by rapidflow analysis (Hanlon et al., 1994). The concentrations of $\mathrm{Ca}, \mathrm{P}, \mathrm{K}$, and $\mathrm{Mg}$ were determined from dry, ashed tissue by inductively coupled plasma emission spectrometry (Hanlon et al., 1994). Concentrations of $\mathrm{N}$ were determined for Expt. 1 and for prebloom and at-bloom applications of Expt. 2. Leaf N 
data were not available for Expt. 3 and for postbloom applications in Expt. 2 .

Tests of significance for main effects of herbicide rate, stage of growth, sampling date, and interactions were conducted using analysis of variance (SAS Release 6.12). Orthogonal polynomials were used to evaluate the nature of the response to increased rates of glyphosate.

\section{Results}

Plant vigor and plant height. Plant vigor decreased as rate of glyphosate increased; however, the most pronounced suppression of vigor occurred with prebloom glyphosate applications (Table 1). More mature plants were less susceptible to the deleterious effects of sublethal rates of glyphosate. Within each stage of development, the suppression of plant vigor was progressive, with losses in vigor apparent by 7 DAT. Marked decline in vigor over time was observed with 60 and $100 \mathrm{~g} \cdot \mathrm{ha}^{-1}$. The lowest plant vigor ratings occurred with the highest glyphosate rate at 28 DAT.

The effect of glyphosate rate and time of assessment after application on plant height did not differ with stage of development in Expt. 1; therefore, data for prebloom and atbloom applications were averaged over stage of development (data not shown). Slowing of growth with 10 and $100 \mathrm{~g} \cdot \mathrm{ha}^{-1}$ glyphosate resulted in a linear decline $(P \leq 0.01)$ in plant height with increasing glyphosate rates by 7 DAT. Applications of $100 \mathrm{~g} \cdot \mathrm{ha}^{-1}$ glyphosate slowed tomato growth to $2.5 \mathrm{~cm}$ over the 4week evaluation period compared with 36.7 $\mathrm{cm}$ for nontreated plants. The profound slowing of growth with $100 \mathrm{~g} \cdot \mathrm{ha}^{-1}$ glyphosate vs. continued growth with the other rates resulted in quadratic responses to increasing glyphosate rates at 14,21 , and $28 \mathrm{DAT}(P \leq 0.05)$. In Expts. 2 and 3, the response to glyphosate rate and time of evaluation differed with the stage of development at application (Table 2). In Expt. 2, plant height, like plant vigor, was affected by glyphosate rate to a lesser degree when application occurred at bloom and postbloom than when applied prebloom. Plant height decreased linearly with increasing rates of glyphosate applied at all stages of development. Differences in height between nontreated plants and plants treated with $100 \mathrm{~g} \cdot \mathrm{ha}^{-1}$ glyphosate increased with time of evaluation after prebloom and at-bloom applications.

The additional rate of $60 \mathrm{~g} \cdot \mathrm{ha}^{-1}$ used in Expt. 3 significantly reduced plant height (Table 2). Decreases in plant height with increasing rates of glyphosate were linear or quadratic in nature and differed with time of evaluation and stage of development at application. The least growth inhibition occurred with plants treated postbloom. The effect of increased glyphosate rate on plant height became more pronounced with time, as growth continued in nontreated plants and plants treated with lower rates of glyphosate, whereas much less growth occurred in plants treated with 60 and $100 \mathrm{~g} \cdot \mathrm{ha}^{-1}$ glyphosate.

Leaf mineral content. Expt. 1. Leaf $\mathrm{N}$ concentration varied with glyphosate rate, stage

Table 1. Effects of sublethal rates of glyphosate and stage of development on tomato plant vigor. ${ }^{2}$

\begin{tabular}{|c|c|c|c|c|c|c|c|c|c|c|c|c|c|}
\hline \multirow{3}{*}{$\begin{array}{l}\text { Rate } \\
\underline{\left(\mathrm{g} \cdot \mathrm{ha}^{-1}\right)}\end{array}$} & \multirow[b]{3}{*}{$\mathrm{DAT}^{\mathrm{y}}$ : } & \multicolumn{12}{|c|}{ Time of treatment } \\
\hline & & \multicolumn{4}{|c|}{ Prebloom } & \multicolumn{4}{|c|}{ At-bloom } & \multicolumn{4}{|c|}{ Postbloom } \\
\hline & & 7 & 14 & 21 & 28 & 7 & 14 & 21 & 28 & 7 & 14 & 21 & 28 \\
\hline \multicolumn{14}{|c|}{ Expt. 1} \\
\hline 0 & & 9.9 & 9.6 & 9.4 & 9.6 & 10.0 & 10.0 & 10.0 & 8.9 & 9.7 & 9.2 & 9.7 & 9.2 \\
\hline 1 & & 9.3 & 9.2 & 9.4 & 8.8 & 9.1 & 9.0 & 8.9 & 8.7 & 9.0 & 9.4 & 9.4 & 8.1 \\
\hline 10 & & 8.0 & 5.4 & 6.3 & 6.8 & 8.5 & 8.0 & 7.3 & 8.1 & 9.3 & 9.2 & 9.0 & 8.2 \\
\hline 100 & & 4.7 & 3.2 & 2.9 & 1.1 & 6.3 & 3.8 & 3.1 & 2.1 & 8.5 & 7.2 & 6.1 & 5.9 \\
\hline Significance & & $\mathrm{Q}^{* *}$ & $\mathrm{Q}^{* *}$ & $\mathrm{Q}^{* *}$ & $\mathrm{Q}^{* *}$ & $\mathrm{Q}^{* *}$ & $\mathrm{Q}^{* *}$ & $\mathrm{Q}^{* *}$ & $\mathrm{~L}^{* *}$ & $\mathrm{~L}^{* *}$ & $\mathrm{~L}^{* *}$ & $\mathrm{~L}^{* *}$ & $\mathrm{~L}^{* *}$ \\
\hline \multicolumn{14}{|c|}{ Expt. 2} \\
\hline & & & & & & & & & & \multicolumn{4}{|c|}{$\operatorname{Mean}^{\mathrm{x}}$} \\
\hline 0 & & 9.8 & 9.2 & 9.2 & 9.4 & 8.6 & 8.9 & 9.0 & 8.8 & \multicolumn{4}{|c|}{9.1} \\
\hline 1 & & 9.4 & 9.3 & 9.2 & 9.1 & 9.3 & 9.4 & 9.3 & 8.7 & \multicolumn{4}{|c|}{9.1} \\
\hline 10 & & 9.2 & 7.8 & 8.3 & 8.3 & 8.6 & 9.1 & 9.1 & 8.9 & \multicolumn{4}{|c|}{8.6} \\
\hline 100 & & 8.3 & 4.8 & 3.9 & 3.1 & 7.7 & 6.8 & 6.8 & 6.3 & \multicolumn{4}{|c|}{8.1} \\
\hline Significance & & $\mathrm{L}^{* *}$ & $\mathrm{Q}^{* *}$ & $\mathrm{~L}^{* *}$ & $\mathrm{~L}^{* *}$ & $\mathrm{~L}^{* *}$ & $\mathrm{~L}^{* *}$ & $\mathrm{~L}^{* *}$ & $\mathrm{~L}^{* *}$ & \multicolumn{4}{|c|}{$\mathrm{Q}^{* *}$} \\
\hline \multicolumn{14}{|c|}{ Expt. 3} \\
\hline 0 & & 9.4 & 9.3 & 9.2 & 8.9 & 9.3 & 9.4 & 9.2 & 8.8 & 9.5 & 9.5 & 9.1 & 9.3 \\
\hline 1 & & 9.3 & 8.7 & 8.5 & 8.2 & 9.2 & 9.0 & 9.0 & 8.6 & 9.2 & 9.1 & 8.7 & 8.8 \\
\hline 6 & & 9.2 & 8.6 & 8.0 & 8.2 & 9.2 & 9.0 & 8.6 & 8.6 & 8.9 & 8.8 & 8.7 & 8.4 \\
\hline 10 & & 9.1 & 7.7 & 7.8 & 8.3 & 9.4 & 8.4 & 8.5 & 8.4 & 8.7 & 8.6 & 8.5 & 8.0 \\
\hline 60 & & 8.8 & 4.0 & 4.2 & 3.9 & 8.6 & 5.8 & 5.4 & 4.4 & 8.7 & 7.6 & 7.3 & 6.7 \\
\hline 100 & & 8.1 & 3.0 & 2.3 & 1.7 & 8.8 & 5.4 & 5.1 & 3.4 & 8.5 & 7.3 & 6.6 & 6.3 \\
\hline Significance & & $\mathrm{L}^{* *}$ & $\mathrm{Q}^{* *}$ & $\mathrm{Q}^{* *}$ & $\mathrm{Q}^{* *}$ & $\mathrm{~L}^{* *}$ & $\mathrm{Q}^{* *}$ & $\mathrm{Q}^{* *}$ & $\mathrm{Q}^{* *}$ & $\mathrm{~L}^{* *}$ & $\mathrm{Q}^{* *}$ & $\mathrm{Q}^{* * *}$ & $\mathrm{Q}^{* *}$ \\
\hline
\end{tabular}

${ }^{\mathrm{z}}$ Vigor was measured on a scale of 10 (100\% vigor) to 0 (death).

${ }^{y} \mathrm{DAT}=$ days after treatment.

xPlant vigor averaged over all evaluation times.

**:Linear (L) and quadratic (Q) effects significant at $P \leq 0.01$.

Table 2. Effects of sublethal rates of glyphosate and stage of development on tomato plant height $(\mathrm{cm})$.

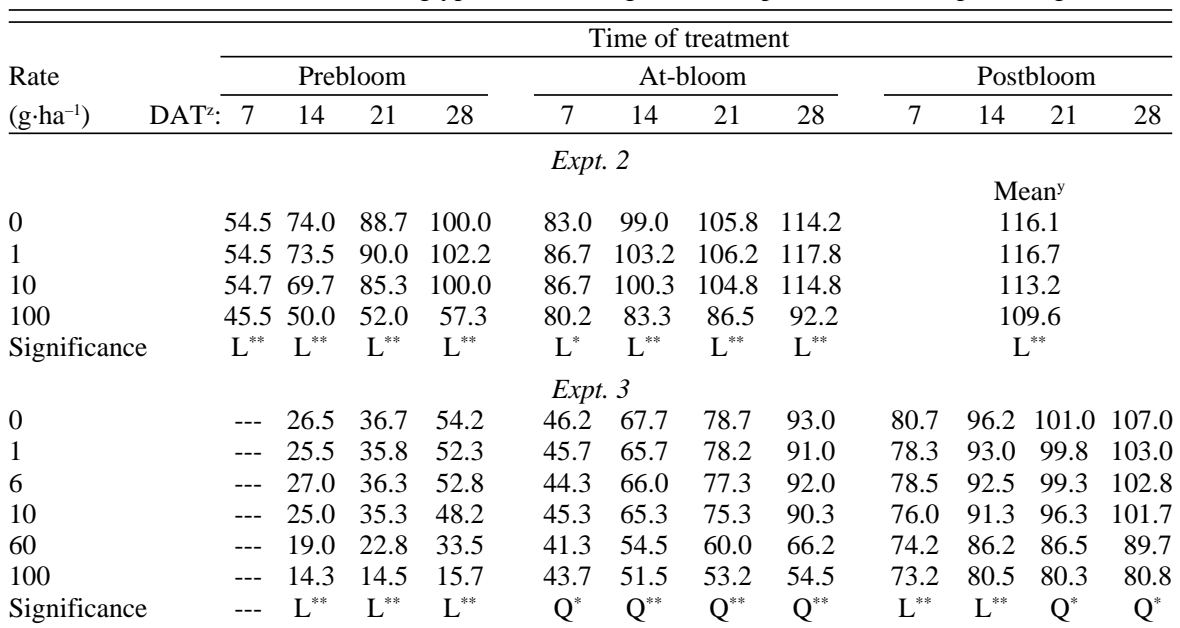

${ }^{\mathrm{z}} \mathrm{DAT}=$ days after treatment.

yPlant height averaged over all sampling times.

*, ${ }^{* *}$ Linear (L) and quadratic (Q) effects significant at $P \leq 0.05$ or 0.01 .

of development, and time of evaluation after treatment $(P=0.0003)$. Increased rates of glyphosate applied prebloom and at-bloom reduced $\mathrm{N}$ concentration of tomato leaves, and the response varied with time after treatment (Table 3). Applications of glyphosate postbloom resulted in a quadratic decrease in leaf $\mathrm{N}$ concentrations from $5.3 \%$ (control) to $4.6 \%$ (100 g.ha ${ }^{-1}$ glyphosate). Generally, glyphosate at $100 \mathrm{~g} \cdot \mathrm{ha}^{-1}$ reduced $\mathrm{N}$ concentration.

The effect of glyphosate exposure at rates from 1 to $100 \mathrm{~g} \cdot \mathrm{ha}^{-1}$ on leaf $\mathrm{P}, \mathrm{K}, \mathrm{Ca}$, and $\mathrm{Mg}$ concentrations was dependent upon the stage of plant development at application $(P=$ 0.0001). Leaf $P$ concentration declined linearly with an increase in glyphosate rates applied at the prebloom and bloom stages, but $\mathrm{P}$ content was unaffected by glyphosate ap- plied postbloom (Fig. 1A). Leaf K concentration decreased linearly with increased glyphosate rates, and the rate of decline was lowest when glyphosate was applied postbloom (Fig. 1B). Glyphosate applied prebloom and at bloom did not influence Ca concentration (Fig. 1C). However, $\mathrm{Ca}$ concentration increased linearly with increasing rates of glyphosate applied postbloom. Concentrations of $\mathrm{Mg}$ were highest with postbloom applications and increased as glyphosate rate was increased from 0 to $10 \mathrm{~g} \cdot \mathrm{ha}^{-1}$ (Fig. 1D). No change in $\mathrm{Mg}$ concentration occurred with increased rates of glyphosate applied prebloom, but the concentration declined linearly with glyphosate applications at bloom.

Expt. 2. Foliar $\mathrm{N}$ data were available for four weekly evaluations after prebloom 
Table 3. Effects of rate and time of application of glyphosate, and time of sampling, on N concentration $(\%)$ of tomato leaves (Expt. 1).

\begin{tabular}{|c|c|c|c|c|c|c|c|c|c|c|}
\hline \multirow{3}{*}{$\begin{array}{l}\text { Rate } \\
\left(\mathrm{g} \cdot \mathrm{ha}^{-1}\right)\end{array}$} & \multirow[b]{3}{*}{ DAT $^{\mathrm{z}}$ : } & \multicolumn{9}{|c|}{ Time of treatment } \\
\hline & & \multicolumn{4}{|c|}{ Prebloom } & \multicolumn{4}{|c|}{ At-bloom } & \multirow[b]{2}{*}{ Postbloom ${ }^{y}$} \\
\hline & & 7 & 14 & 21 & 28 & 7 & 14 & 21 & 28 & \\
\hline$\overline{0}$ & & 5.6 & 5.6 & 5.6 & 5.1 & 5.4 & 5.4 & 5.5 & 4.4 & 5.3 \\
\hline 1 & & 5.7 & 5.5 & 5.3 & 4.6 & 6.0 & 5.3 & 5.4 & 5.6 & 5.4 \\
\hline 10 & & 5.1 & 5.0 & 5.8 & 5.3 & 5.6 & 5.1 & 5.1 & 5.6 & 4.8 \\
\hline 100 & & 4.4 & 3.9 & 4.1 & 4.2 & 4.7 & 4.1 & 3.8 & 3.9 & 4.6 \\
\hline Significance & & $\mathrm{Q}^{*}$ & $\mathrm{Q}^{*}$ & $\mathrm{~L}^{* *}$ & $\mathrm{Q}^{*}$ & $\mathrm{~L}^{* *}$ & $\mathrm{~L}^{* *}$ & $\mathrm{~L}^{* *}$ & $\mathrm{Q}^{* *}$ & $\mathrm{Q}^{* *}$ \\
\hline
\end{tabular}

${ }^{\mathrm{z}} \mathrm{DAT}=$ days after treatment.

${ }^{\mathrm{y}} \mathrm{N}$ concentration averaged over all sampling times.

${ }^{*}, *$ Linear (L) and quadratic (Q) effects significant at $P \leq 0.05$ and 0.01 .
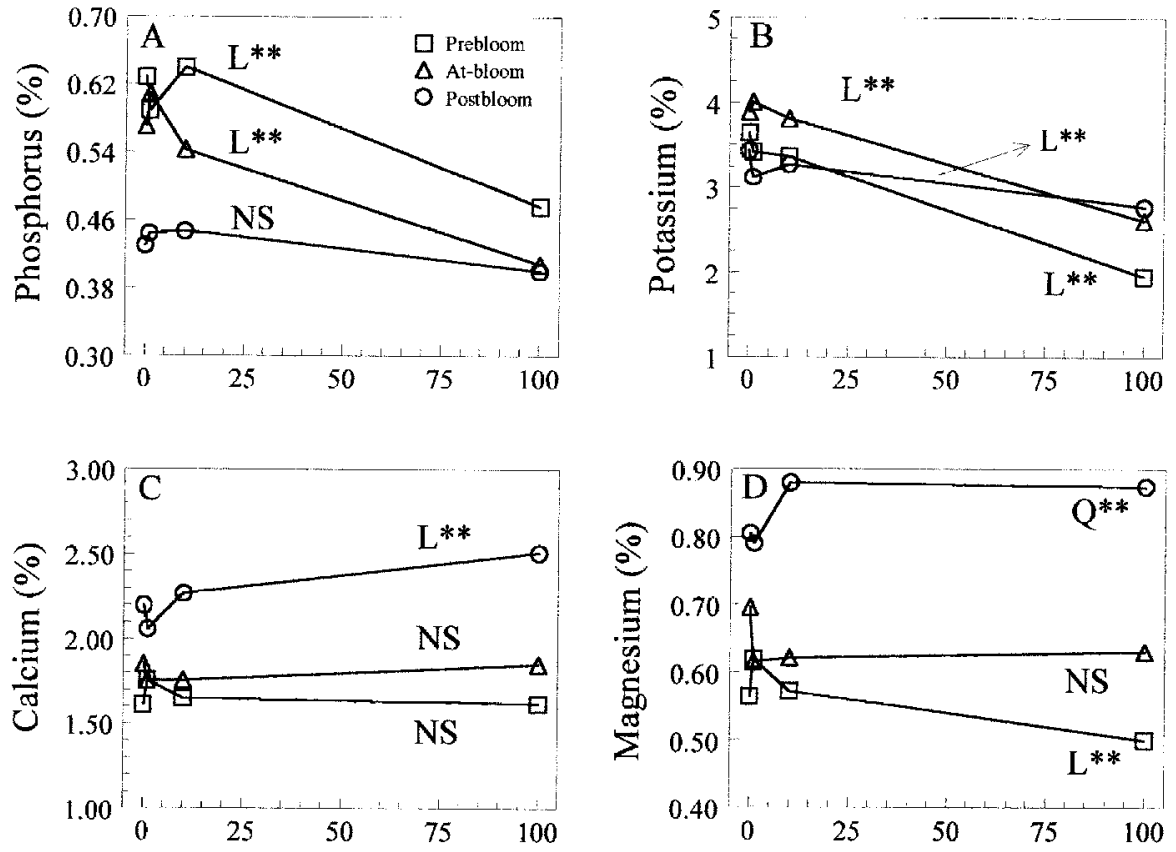

Glyphosate $\left(g \cdot h a^{-1}\right)$

Fig. 1. Effects of glyphosate rate and stage of development on mineral content of tomato leaves (Expt. 1).

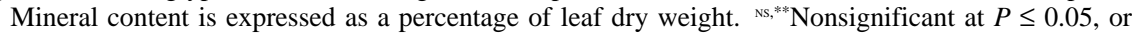
significant at $P \leq 0.01$, respectively, for linear (L) and quadratic (Q) effects of glyphosate rate.

glyphosate applications, and for 1 and 2 weeks after at-bloom applications. Nitrogen concentration declined linearly from $5.1 \%$ with no glyphosate to $4.4 \%$ with $100 \mathrm{~g} \cdot \mathrm{ha}^{-1}$ glyphosate applied prebloom $(P=0.0001$, data not shown), when averaged over time of evaluation. Glyphosate applied at bloom did not affect leaf $\mathrm{N}$ concentration.

The foliar concentrations of $\mathrm{P}, \mathrm{K}, \mathrm{Ca}$, and $\mathrm{Mg}$ varied with glyphosate rate, stage of development, and time of evaluation. Increased rates of glyphosate from 0 to 100 $\mathrm{g} \cdot \mathrm{ha}^{-1}$ applied prebloom decreased leaf $\mathrm{P}$ concentration by $23 \%$ (Table 4 ), but had no effect when applied at bloom (data not shown). Unlike the earlier stages of development, the effect of glyphosate applied postbloom on foliar $\mathrm{P}$ concentration differed with time of evaluation (Table 4). Response to glyphosate rate was not consistent over the 7 - to 28 -d evaluation period.
Foliar K concentration decreased linearly with increased rates of glyphosate applied prebloom at all times of evaluation (Table 4), but treatment at bloom had no effect on $\mathrm{K}$ concentration (data not shown). Although the initial samples taken $7 \mathrm{~d}$ after postbloom application indicated that $\mathrm{K}$ concentration increased with glyphosate rate, the response varied with time of evaluation (Table 4).

At 7 and $14 \mathrm{~d}$ after prebloom applications, leaf $\mathrm{Ca}$ increased with rate of glyphosate; however, at 21 and 28 DAT glyphosate had no significant effect (Table 4). Glyphosate applied at bloom also had no effect on leaf $\mathrm{Ca}$ (data not shown). The effect of glyphosate applied postbloom was inconsistent (Table 4).

With prebloom glyphosate applications, $\mathrm{Mg}$ concentration increased linearly with rate at all sampled times, with a greater increase occurring at 7 DAT than at later times of evaluation (Table 4). Leaf Mg concentration increased linearly by $7 \%$ as glyphosate, applied at-bloom, increased from 0 to $100 \mathrm{~g} \cdot \mathrm{ha}^{-1}$ $(P<0.01$, data not shown). The leaf $\mathrm{Mg}$ response to postbloom glyphosate applications varied with time of evaluation. At 7 DAT, leaf $\mathrm{Mg}$ increased linearly with glyphosate rate, but no response was apparent at 28 DAT (Table 4).

Expt. 3. The response of foliar $\mathrm{P}, \mathrm{K}, \mathrm{Ca}$, and $\mathrm{Mg}$ to glyphosate rate differed with stage of development at application and time of leaf sampling $(P \leq 0.0001)$. The sensitivity of $\mathrm{N}, \mathrm{P}$, and $\mathrm{K}$ concentrations to increased rates of glyphosate applied prebloom observed in earlier experiments was not apparent in Expt. 3 (Table 5). The response of leaf $\mathrm{P}$ to increased glyphosate rates at all stages of development was cubic. Prebloom applications of 1 to $10 \mathrm{~g} \cdot \mathrm{ha}^{-1}$ glyphosate caused $\mathrm{P}$ concentrations to decline progressively; however, $\mathrm{P}$ concentrations were higher with rates of 60 and $100 \mathrm{~g} \cdot \mathrm{ha}^{-1}$ glyphosate than those with $10 \mathrm{~g} \cdot \mathrm{ha}^{-1}$ (Table 5). The response to increasing rates of glyphosate applied at bloom was also cubic. Although $P$ concentrations decreased as glyphosate rates increased to $10 \mathrm{~g} \cdot \mathrm{ha}^{-1}, 60$ and $100 \mathrm{~g} \cdot \mathrm{ha}^{-1}$ glyphosate either increased or had no further effect on $P$ concentration. At 7 DAT, P concentration was unaffected by postbloom glyphosate applications at rates of $10 \mathrm{~g} \cdot \mathrm{ha}^{-1}$ or less; however, a marked increase in $\mathrm{P}$ concentration occurred with 60 and $100 \mathrm{~g} \cdot \mathrm{ha}^{-1}$. In contrast, at $14 \mathrm{DAT}$, $\mathrm{P}$ concentrations increased with $10 \mathrm{~g} \cdot \mathrm{ha}^{-1}$ of glyphosate or less applied postbloom, but declined to a low of $0.48 \%$ following application of $100 \mathrm{~g} \cdot \mathrm{ha}^{-1}$. For leaves sampled 21 and 28 DAT, the lowest P concentrations were observed with $10 \mathrm{~g} \cdot \mathrm{ha}^{-1}$ glyphosate.

Seven days after prebloom applications, leaf $\mathrm{K}$ first increased with increasing glyphosate rate, then declined with further increases in a quadratic manner (Table 5). At subsequent times of evaluation, glyphosate rates of less than $10 \mathrm{~g} \cdot \mathrm{ha}^{-1}$ initially reduced foliar $\mathrm{K}$, which was followed by recovery or an increase in $\mathrm{K}$ concentration with 60 or $100 \mathrm{~g} \cdot \mathrm{ha}^{-1}$ glyphosate. With glyphosate applications atbloom, K concentration changed significantly at only the first two times of evaluation. Seven days after postbloom glyphosate applications, $\mathrm{K}$ concentrations increased linearly with glyphosate rate, but response was inconsistent at subsequent times of evaluation. Similarly for $\mathrm{Ca}$ and $\mathrm{Mg}$ concentrations, glyphosate application at all three stages of development produced significant responses for some or all times of evaluation; however, response was not consistent over time.

\section{Discussion}

The primary mechanism of action of glyphosate is the inhibition of 5-enolpyruvylshikimate-3-phosphate synthase, disrupting the biosynthesis of the aromatic amino acids tryptophan, tyrosine, and phenylalanine (Cole, 1985). Symptoms of glyphosate exposure include growth inhibition within days of application and subsequent foliar chlorosis and 
necrosis over a 1- to 3-week period (Ahrens, 1994). Therefore, we anticipated that sublethal rates of glyphosate would affect plant vigor and depress plant height, and that rates that produced significant changes in these plant parameters would influence leaf mineral content. The self-limitation of glyphosate translocation has been attributed to a disruption in photosynthesis, leading to reduced translocation of carbon (Geiger and Bestman, 1990; Geiger et al., 1999). Translocation of assimilates out of source leaves and import of assimilates by sink leaves were inhibited. Marschner et al. (1997) reported that cycling and recycling of nutrients such as $\mathrm{N}, \mathrm{P}, \mathrm{K}, \mathrm{S}$, and $\mathrm{Mg}$ are closely related to phloem loading and export of photosynthate by source leaves. As a result, we expected that disruptions of photosynthesis and translocation by glyphosate would affect phloem-mobile elements to a greater extent than the less phloem-mobile $\mathrm{Ca}$.

In the current study, glyphosate application rates of 60 and $100 \mathrm{~g} \cdot \mathrm{ha}^{-1}$ consistently reduced plant vigor and height. Similar pronounced changes in leaf mineral content were expected in response to glyphosate, particularly at the earlier stages of development prior to flowering. This was not consistently so and may be due to seasonal differences in sensitivity to glyphosate or other differences in physiological status that caused variable responses to sublethal glyphosate rates. Nutrient absorption occurs throughout the growth and development of tomato plants (Wilcox, 1993), and stunting was observed in this study with 60 and $100 \mathrm{~g} \cdot \mathrm{ha}^{-1}$ glyphosate. Thus, the higher concentrations of $\mathrm{P}$ in plants treated with 60 and $100 \mathrm{~g} \cdot \mathrm{ha}^{-1}$ glyphosate in Expt. 3, than those treated with $10 \mathrm{~g} \cdot \mathrm{ha}^{-1}$, may indicate similar $\mathrm{P}$ accumulation but reduced growth at the higher rates. Since the mineral analyses were conducted on the youngest mature leaf, which was sampled at weekly intervals for 4 weeks, the status of sampled leaves as a source or sink at the time of glyphosate application may have contributed to inconsistencies among times of evaluation.

We conclude that tomato leaf mineral content was affected by sublethal rates of glyphosate applied prebloom, at-bloom and postbloom; however, foliar mineral content was a less reliable indicator of sublethal glyphosate exposure than were plant vigor and plant height. Of the minerals assessed, the decrease in leaf $\mathrm{N}$ concentration with increasing rates of glyphosate was the most consistent change over the 4-week evaluation period.

Table 4. Effects of glyphosate rate and stage of development on mineral content (\% DW) of tomato leaves (Expt. 2).

\begin{tabular}{|c|c|c|c|c|c|c|c|c|c|c|c|c|c|c|c|c|c|}
\hline \multirow{2}{*}{$\begin{array}{l}\text { Rate } \\
\left(\mathrm{g} \cdot \mathrm{ha}^{-1}\right)\end{array}$} & \multirow[b]{2}{*}{$\mathrm{DAT}^{\mathrm{z}}$ : } & \multicolumn{4}{|c|}{ Phosphorus } & \multicolumn{4}{|c|}{ Potassium } & \multicolumn{4}{|c|}{ Calcium } & \multicolumn{4}{|c|}{ Magnesium } \\
\hline & & 7 & 14 & 21 & 28 & 7 & 14 & 21 & 28 & 7 & 14 & 21 & 28 & 7 & 14 & 21 & 28 \\
\hline \multicolumn{18}{|c|}{ Prebloom } \\
\hline 0 & \multicolumn{5}{|c|}{$0.49^{y}$} & 4.4 & 4.3 & 3.8 & 4.4 & 1.9 & 1.9 & 2.1 & 2.4 & 0.64 & 0.64 & 0.65 & 0.74 \\
\hline 1 & \multicolumn{5}{|c|}{0.50} & 4.4 & 4.2 & 4.3 & 4.0 & 2.0 & 1.8 & 1.9 & 2.4 & 0.68 & 0.64 & 0.65 & 0.75 \\
\hline 10 & \multicolumn{5}{|c|}{0.48} & 4.2 & 4.1 & 3.8 & 4.0 & 1.9 & 1.8 & 1.9 & 2.2 & 0.64 & 0.64 & 0.64 & 0.74 \\
\hline 100 & \multicolumn{5}{|c|}{0.38} & 2.6 & 3.7 & 3.1 & 2.7 & 2.7 & 2.1 & 2.1 & 2.5 & 0.93 & 0.77 & 0.74 & 0.81 \\
\hline Significance & \multicolumn{5}{|c|}{$\mathrm{L}^{* *}$} & $\mathrm{~L}^{* *}$ & $\mathrm{~L}^{*}$ & $\mathrm{~L}^{* *}$ & $\mathrm{~L}^{* *}$ & $\mathrm{~L}^{* *}$ & $\mathrm{~L}^{*}$ & NS & NS & $\mathrm{L}^{* *}$ & $\mathrm{~L}^{* *}$ & $\mathrm{~L}^{* *}$ & $\mathrm{~L}^{*}$ \\
\hline \multicolumn{18}{|c|}{ Postbloom } \\
\hline 0 & & 0.45 & 0.49 & 0.61 & 0.39 & 2.6 & 3.6 & 4.3 & 3.0 & 1.6 & 2.3 & 2.1 & 2.1 & 0.56 & 0.78 & 0.69 & 0.67 \\
\hline 1 & & 0.41 & 0.42 & 0.59 & 0.32 & 2.3 & 3.8 & 3.9 & 3.0 & 1.6 & 2.3 & 2.2 & 1.9 & 0.53 & 0.82 & 0.73 & 0.66 \\
\hline 10 & & 0.52 & 0.32 & 0.60 & 0.57 & 3.5 & 2.6 & 4.4 & 3.7 & 2.0 & 1.8 & 2.3 & 2.1 & 0.63 & 0.64 & 0.81 & 0.65 \\
\hline 100 & & 0.49 & 0.33 & 0.56 & 0.53 & 4.0 & 2.9 & 3.9 & 3.7 & 1.9 & 1.6 & 2.4 & 2.1 & 0.68 & 0.57 & 0.76 & 0.67 \\
\hline Significance & & $\mathrm{Q}^{* *}$ & $\mathrm{Q}^{* *}$ & NS & $\mathrm{Q}^{* *}$ & $\mathrm{Q}^{* *}$ & $\mathrm{Q}^{* *}$ & NS & $\mathrm{Q}^{*}$ & $\mathrm{Q}^{* *}$ & $\mathrm{Q}^{* * *}$ & $\mathrm{~L}^{*}$ & NS & $\mathrm{L}^{* *}$ & $\mathrm{Q}^{* *}$ & $\mathrm{Q}^{*}$ & NS \\
\hline
\end{tabular}

${ }^{2}$ DAT $=$ days after treatment.

${ }^{\mathrm{y}}$ Phosphorus content with prebloom glyphosate applications averaged over all sampling times.

Ns, ****Nonsignificant, and significant at $P \leq 0.05$ and 0.01 , respectively, for linear (L) and quadratic (Q) effects.

Table 5. Effects of glyphosate rate and stage of development on mineral content (\% DW) of tomato leaves (Expt. 3).

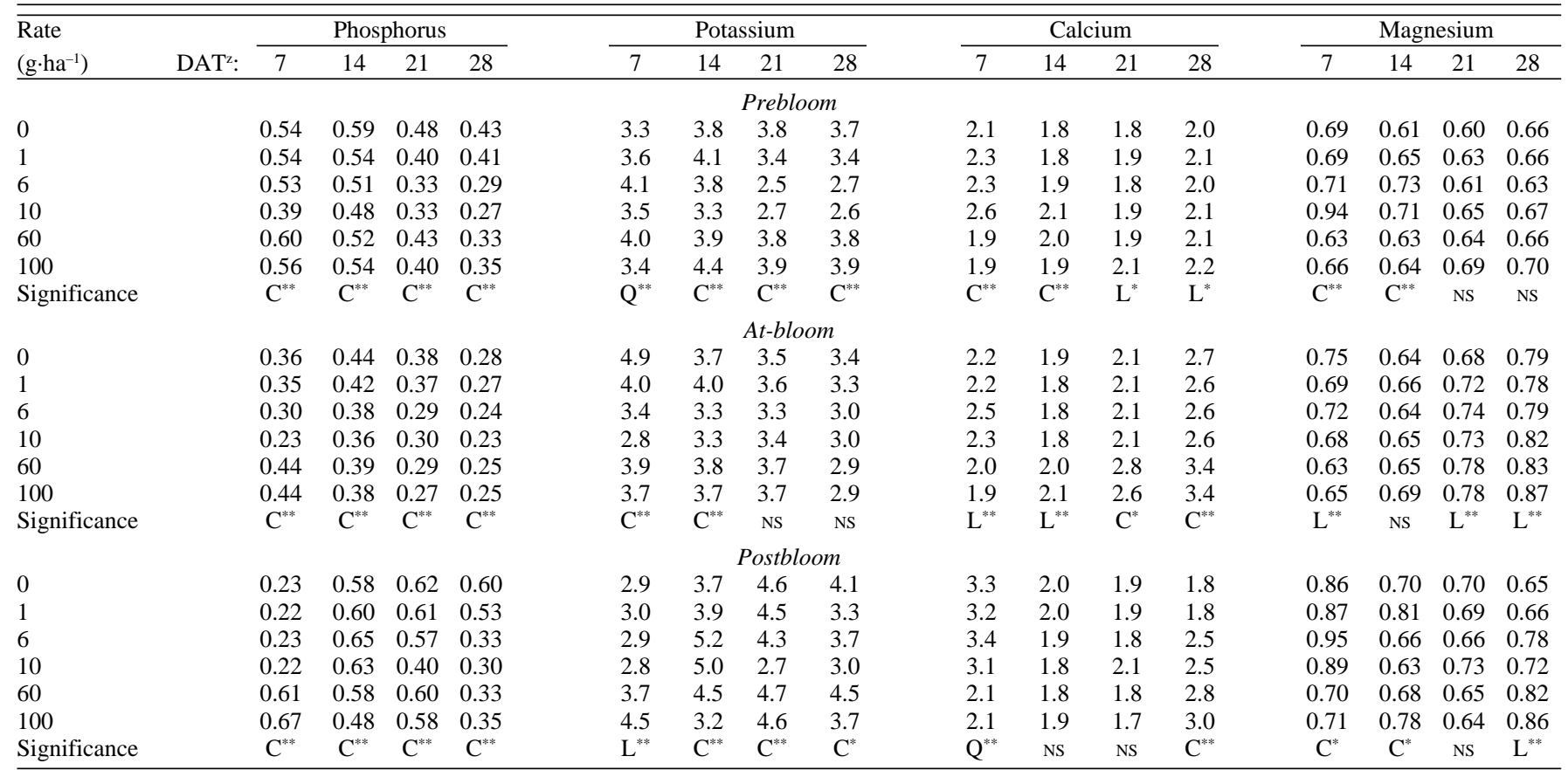

${ }^{\mathrm{L}} \mathrm{DAT}=$ Days after treatment.

Ns, ****Nonsignificant and significant at $P \leq 0.05$ and 0.01 , respectively, for linear (L), quadratic (Q), or cubic (C) effects. 
Consistency of response over time is important for diagnostic purposes since the time of exposure is often unknown and physical symptoms of glyphosate injury on foliage often develop slowly. A more direct measurement of the presence of glyphosate is determination of shikimate content (Singh and Shaner, 1998) and this may serve as a more reliable tool than leaf mineral analysis. Although significant changes in foliar $\mathrm{N}, \mathrm{P}, \mathrm{K}, \mathrm{Ca}$, and $\mathrm{Mg}$ were observed in response to sublethal rates of glyphosate, mineral deficiencies (Maynard and Hochmuth, 1997) did not occur at rates up to $100 \mathrm{~g} \cdot \mathrm{ha}^{-1}$.

\section{Literature Cited}

Ahrens, W.H. 1994. Herbicide handbook. $7^{\text {th }}$ ed. Weed Sci. Soc. of Amer., Champaign, Ill.

Brecke, B.J. and W.B. Duke. 1980. Effect of glyphosate on intact bean plants (Phaseolus vulgaris $\mathrm{L}$.) and isolated cells. Plant Physiol. 66:656-659.
Cole, D.J. 1985. Mode of action of glyphosate-A literature analysis, p. 48-74. In: E. Grossbard and D. Atkinson (eds.). The herbicide glyphosate. Butterworths, London.

Duke, S.O., K.C. Vaughn, and R.D. Wauchope. 1985. Effects of glyphosate on uptake, translocation, and intracellular localization of metal cations in soybeans (Glycine max) seedlings. Pest. Biochem. Physiol. 24:384-394.

Duke, S.O., R.D. Wauchope, R.E. Hoagland, and G.D. Wills. 1983. Influence of glyphosate on uptake and translocation of calcium ion in soybean seedlings. Weed Res. 23:133-139.

Franz, J.E. 1985. Discovery, development and chemistry of glyphosate, p. 3-17. In: E. Grossbard and D. Atkinson (eds.). The herbicide glyphosate. Butterworths, London.

Geiger, D.R. and H.D. Bestman. 1990. Self-limitation of herbicide mobility by phytotoxic action. Weed Sci. 38:324-329.

Geiger, D.R., W.J. Shieh, and M.A. Fuchs. 1999. Causes of self-limited translocation of glyphosate in Beta vulgaris plants. Pestic. Biochem. Physiol. 64:124-133.

Hanlon, E.A., J.G. Gonzalez, and J.M. Bartos.
1994. Institute of Food and Agricultural Sciences extension soil testing laboratory chemical procedures and training manual. Florida Coop. Ext. Serv. Circ. 812.

Marschner, H., E.A. Kirby, and C. Engels. 1997. Importance of cycling and recycling of mineral nutrients within plants for growth and development. Botanica Acta 110:265-273.

Maynard, D.N. and G.J. Hochmuth. 1997. Knott's handbook for vegetable growers. $4^{\text {th }} \mathrm{ed}$. Wiley, New York.

Powles, S.B., D.F. Lorraine-Colwill, J.J. Dellow, and C. Preston. 1998. Evolved resistance to glyphosate in rigid ryegrass (Lolium rigidum). Weed Sci. 46:604-607.

Romanowski, R.R. 1980. Simulated drift studies with herbicides on field-grown tomato. HortScience 15:793-794.

Singh, B.K. and D.L. Shaner. 1998. Rapid determination of glyphosate injury to plants and identification of glyphosate-resistant plants. Weed Tech. 12:527-530.

Wilcox, G.E. 1993. Tomato, p. 137-141. In: W.F Bennett (ed.). Nutrient deficiencies and toxicities in crop plants. APS Press, St. Paul, Minn. 